NBER WORKING PAPER SERIES

\title{
ARE RESETTLED OUSTEES FROM THE SARDAR SAROVAR DAM PROJECT BETTER OFF TODAY THAN THEIR FORMER NEIGHBORS WHO WERE NOT OUSTED?
}

\author{
Swaminathan S. Anklesaria Aiyar \\ Neeraj Kaushal \\ Working Paper 24423 \\ http://www.nber.org/papers/w24423
NATIONAL BUREAU OF ECONOMIC RESEARCH
1050 Massachusetts Avenue
Cambridge, MA 02138
March 2018

The authors thank the International Growth Centre, London School of Economics and Political Science for funding this project and researchers at Karvy Insights for assistance in survey design, data collection, and analysis. The views expressed herein are those of the authors and do not necessarily reflect the views of the National Bureau of Economic Research.

NBER working papers are circulated for discussion and comment purposes. They have not been peer-reviewed or been subject to the review by the NBER Board of Directors that accompanies official NBER publications.

(C) 2018 by Swaminathan S. Anklesaria Aiyar and Neeraj Kaushal. All rights reserved. Short sections of text, not to exceed two paragraphs, may be quoted without explicit permission provided that full credit, including $(\odot$ notice, is given to the source. 
Are Resettled Oustees from the Sardar Sarovar Dam Project Better off Today than their Former

Neighbors who were not Ousted?

Swaminathan S. Anklesaria Aiyar and Neeraj Kaushal

NBER Working Paper No. 24423

March 2018

JEL No. H1,H13,H75,I0

\section{ABSTRACT}

The Sardar Sarovar Dam in Gujarat is arguably the most controversial dam ever built in India, with over a 100,000 displaced people. Most ousted families in Gujarat were resettled in the late 1980s and early 1990s. All oustees were tribals - a term used in India to cover a list of tribes viewed as so backward and historically oppressed that the Indian Constitution in 1950 reserved a quota of seats in education, government jobs, and Parliamentary seats for them. The Gujarat government promised to offer each male adult in the ousted families above the age of 18 five acres of land regardless of their earlier forest holdings. Additional compensation was to be given for loss of houses and livestock. Despite the continuing opposition to the dam from influential NGOs, there is no systematic empirical study of its effects on the long-term wellbeing of the ousted families. Our study investigates: Are resettled oustees from the Sardar Sarovar Dam project better off in 2017, approximately three decades after resettlement, than their former neighbours who were not ousted?

We carried out a survey of a randomly selected sample of outsted families (treatment group) and a randomly selected sample of their former neighbors who lived in high areas that would remain above water when the reservoir rises to its maximum height and therefore were allowed to stay (comparison group). We found that, despite implementation glitches, those displaced were far better off than their former forest neighbours in ownership of a range of assets including TVs, cellphones, vehicles, access to schools and hospitals, and agricultural markets. The gap in asset ownership and other outcomes between the treatment and comparison groups were often statistically larger if the heads of the household were illiterate compared to the gap if they were literate. This finding suggests that resettlement helped vulnerable groups more than the less vulnerable and that fears that resettlement will destroy the lives and life-styles of tribals have been grossly exaggerated.

We also found that $54 \%$ of displaced folk wished to return to their old habitat, showing that nostalgia for ancestral land can matter more than onweship of assets and economic wellbeing. Nearby undisplaced forest dwellers were asked if they would like to be "forcibly" resettled with the full compensation package. Of two forest groups, 31\% and 52\% said yes. Clearly many, though not all, tribesfolk yearn to leave the forest.

Swaminathan S. Anklesaria Aiyar

Cato Institute

1000 Massachusetts Ave, NW

Washington, DC 20001-5403

swamiaiyar@yahoo.com

Neeraj Kaushal

Columbia University

School of Social Work

1255 Amsterdam Avenue

New York, NY 10027

and NBER

nk464@columbia.edu 


\begin{abstract}
The Sardar Sarovar Dam in Gujarat is arguably the most controversial dam ever built in India, with over a 100,000 displaced people. Most ousted families in Gujarat were resettled in the late 1980s and early 1990s. All oustees were tribals--- a term used in India to cover a list of tribes viewed as so backward and historically oppressed that the Indian Constitution in 1950 reserved a quota of seats in education, government jobs, and Parliamentary seats for them. The Gujarat government promised to offer each male adult in the ousted families above the age of 18 five acres of land regardless of their earlier forest holdings. Additional compensation was to be given for loss of houses and livestock. Despite the continuing opposition to the dam from influential NGOs, there is no systematic empirical study of its effects on the long-term wellbeing of the ousted families. Our study investigates: Are resettled oustees from the Sardar Sarovar Dam project better off in 2017, approximately three decades after resettlement, than their former neighbours who were not ousted?

We carried out a survey of a randomly selected sample of outsted families (treatment group) and a randomly selected sample of their former neighbors who lived in high areas that would remain above water when the reservoir rises to its maximum height and therefore were allowed to stay (comparison group). We found that, despite implementation glitches, those displaced were far better off than their former forest neighbours in ownership of a range of assets including TVs, cellphones, vehicles, access to schools and hospitals, and agricultural markets. The gap in asset ownership and other outcomes between the treatment and comparison groups were often statistically larger if the heads of the household were illiterate compared to the gap if they were literate. This finding suggests that resettlement helped vulnerable groups more than the less vulnerable and that fears that resettlement will destroy the lives and life-styles of tribals have been grossly exaggerated.

We also found that $54 \%$ of displaced folk wished to return to their old habitat, showing that nostalgia for ancestral land can matter more than onweship of assets and economic wellbeing. Nearby undisplaced forest dwellers were asked if they would like to be "forcibly" resettled with the full compensation package. Of two forest groups, 31\% and 52\% said yes. Clearly many, though not all, tribesfolk yearn to leave the forest.
\end{abstract}




\section{Introduction}

The Sardar Sarovar Dam in Gujarat is arguably the most controversial dam ever built in India, with over a 100,000 displaced people. All oustees were tribals--- a term used in India to cover a list of tribes viewed as so backward and historically oppressed that, as a measure of affirmative action, the Indian Constitution in 1950 reserved a quota of seats in education, government jobs, and Parliamentary seats for them. A number of activists led by Medha Patkar have long claimed that, despite land and other forms of compensation, the tribals forced to move will be worse off, and will suffer social ostracism and humiliation in the resettlement villages (Patkar,1995, 2017, Baviskar, 1995, 1997, Hakim, 1997). Others like the Morse Commission set up by the World Bank expressed concerns that tribal communities engaged in subsistence agriculture in forests would not be able to cope with the shift to market oriented farming in resettlement areas; that they would get entangled in debt cycles, losing land to money-lenders or local landowners, and that, overall, resettlement would render a serious blow to their tribal customs and ways of life (Morse and Berger, 1992). ${ }^{1}$

Most tribals in Gujarat were resettled in the late 1980s and early 1990s. The Gujarat government promised to offer each male adult above the age of 18 five acres of land regardless of their earlier forest holdings which, from the Forest Department's viewpoint, was largely encroached and not legally owned land. Additional compensation was to be given for loss of houses and livestock. The government identified large expanse of land in the command area of the project where farmers (mostly of the dominant Patel caste) were willing to sell. With the help of NGOs, tribal groups were shown the available areas and given the right to choose compensatory land.

Would the oustees have been better off had there been no dam? Despite the continuing debates on how dams affect the wellbeing of ousted populations, there is little systematic research to answer this question. Investigating how resettlement impacted the lives of the oustees three decades after the event is not an easy task. Besides lack of comparable pre- and post-resettlement data on the oustees, there are challenges in parsing out the effect of resettlement from the effects of other events and developments that influenced their lives since resettlement.

We adopt a novel approach that involves comparing the living conditions of resettled tribals with tribals living in semi-evacuated villages. The semi-evacuated villages have partially submerged areas (in low-lying areas) and areas partly above water (in higher areas) that will remain above water when the reservoir rises to its maximum height. Tribal families in the higher areas therefore have not been forced to move. This becomes a natural comparison group for the

\footnotetext{
${ }^{1}$ Several other groups expressed similar concerns. A publication from the Third World Network, Malaysia notes, "Besides displacement, this will affect the tribals' very culture and basis of their livelihood, their beliefs, myths and rituals, their festivals, songs and dances, all closely associated with the hills, woods and streams. As these disintegrate in their new harsh surroundings, so too will the joy of their existence." (Alvares \& Billorey, 1987).
} 
tribals who were forced to move. We also study the wellbeing of a third group of tribals in villages within 15-20 kilometers radius of the project affected area, who therefore have some knowledge of the resettlement package and its implementation. For convenience, we call this group interior villages.

We study the living conditions and wellbeing of the three groups - oustees, households in semi-submerged villages, and households in the interior villages - on multiple dimensions including, asset ownership, housing and living conditions, occupation, agricultural practices, awareness and utilization of government programs and services -- to investigate if the resettled tribals are better- or worse-off compared to the other two groups.

Our survey also collected data on oustees' views on resettlement and how it impacted their religious practices, rituals and customs, attire and experience of resettlement. Further, we asked the resettled families whether they agreed or disagreed with the following statement. "If the government offers the exact amount of land you had earlier in the higher un-submerged part of your old village in exchange for the land you have today, you will accept it." Likewise, we asked respondents in semi-evacuated and interior villages to rank their agreement with the following statement: "I would be willing to give up my land, livestock and accept the government's rehabilitation package today." We believe this is a unique approach and can inform ongoing debates of the effects of resettlement that have generally been carried out without actual or updated data on the experience and opinions of tribals themselves.

\section{Previous Research}

Most studies on the effect resettlement of oustees in the Narmada Valley have been conducted in the 1980s and early 1990s and focus on the process of resettlement or the wellbeing of the oustees soon after resettlement (Baviskar, 1995, 1997, Hakim, 1997, Bhatia, 1997). Many of these studies raise doubts about the success of resettlement on grounds that tribals have life styles that cannot be replicated in resettled areas or that tribal attitudes and expectations, agricultural and cultural practices make them unfit for non-tribal lifestyles, and therefore, resettlement will not succeed. Others had a more positive attitude towards resettlement, as summarized in Vidyut Joshi's remark. "When someone says that the tribals have a different culture and that their culture must be preserved, it is a denial of their right for development" (Joshi, 1997).

A weakness of many previous studies is that they do not distinguish between transitional and long-term effects, and tend to highlight the transitional ones. Whatever the uses of that approach, it does not address how the ousted tribals have fared in the long term, the issue that we address in our survey. Nor have earlier studies asked undisplaced tribals if they would like to move and be resettled with the government's compensation package. 


\section{Survey Design}

We surveyed a randomly selected sample of 401 tribal households resettled in 25 large villages (the sample size would be too small, sometimes just one household, in smaller resettlements). Our power analysis showed that a sample size of 400 will have a sampling error of $\pm 4.2 \%$ at $95 \%$ confidence interval. ${ }^{2}$ Based on this analysis, we determined the sample sizes of the three groups.

Similar sized random samples were taken, each, from four semi-evacuated villages ${ }^{3}$ and nine interior villages. The sample of oustee households was representative of the two rehabilitation phases (phase 1: mostly 1980-1983, completed by 1989 and phase 2: 1989-1995) and tribal groups. We obtained the list of oustees from the Sardar Sarovar Punarvasvat Agency, the resettlement agency (SSPA) from which a representative random sample of oustee households was drawn.

We used the voter list from the Election Commission for the families in the semievacuated and interior villagers and drew random samples of each group. The survey was contracted out to Karvy Insights and conducted in May-June 2017.

Karvy Insights also conducted a qualitative study that included in depth interviews with key stakeholders and focus group discussions with ousted families, families in semi-evacuated, and interior villages. We report its main findings in the Results section here.

One characteristic of the interior villages is that two of them (30\% of the sample) are located near mines developed by the Gujarat Mineral Development Corporation. GMDC has built medical and other infrastructural facilities from which the villagers benefited. Three other villages (39\% of the sample) received drinking water and several other facilities from the Sardar Sarovar Project. This gives some interior villagers an advantage in some respects and makes them a somewhat inappropriate group for comparison. We therefore present and discuss results for the ousted families and families in the semi-submerged areas. The results for the interior villages are presented in the appendix.

\footnotetext{
${ }^{2}$ In sample surveys, an error of $5-7 \%$ is considered normal.

${ }^{3}$ Of the six partially sub-merged villages, two had no residents at the time of the survey.
} 


\section{Results}

Quantitative Survey

Asset Ownership \& Housing

Table 1: Asset Ownership

\begin{tabular}{|c|c|c|c|c|c|c|c|c|c|c|}
\hline & \multicolumn{3}{|c|}{ All } & \multicolumn{3}{|c|}{ Literate } & \multicolumn{3}{|c|}{ Illiterate } & \\
\hline & Resettled & $\begin{array}{r}\text { Semi- } \\
\text { Submerged }\end{array}$ & Diff & Resettled & $\begin{array}{r}\text { Semi- } \\
\text { submerged }\end{array}$ & Diff & Resettled & $\begin{array}{r}\text { Semi- } \\
\text { submerged }\end{array}$ & Diff & \\
\hline & $\mathrm{I}$ & Now & $\mathrm{III}=\mathrm{I}-\mathrm{II}$ & IV & 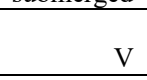 & $\begin{array}{r}\mathrm{VI}= \\
\mathrm{IV}-\mathrm{V}\end{array}$ & VII & VIII & $\begin{array}{r}\mathrm{XI}=\mathrm{VII}- \\
\mathrm{VIII}\end{array}$ & $\mathrm{X}$ \\
\hline & $\%$ & $\%$ & $\%$ & $\%$ & $\%$ & $\%$ & $\%$ & $\%$ & $\%$ & \\
\hline Bicycles & $\begin{array}{l}65.0 \\
(2.4)\end{array}$ & $\begin{array}{l}31.4 \\
(2.3)\end{array}$ & $\begin{array}{r}33.7 * \\
(3.3)\end{array}$ & $\begin{array}{l}70.6 \\
(3.0)\end{array}$ & $\begin{array}{l}54.0 \\
(4.5)\end{array}$ & $\begin{array}{r}16.6^{*} \\
(5.2)\end{array}$ & $\begin{array}{l}57.1 \\
(3.9)\end{array}$ & $\begin{array}{l}21.3 \\
(2.5)\end{array}$ & $\begin{array}{r}35.8^{*} \\
(4.4)\end{array}$ & + \\
\hline Two-wheelers & $\begin{array}{l}61.4 \\
(2.4)\end{array}$ & $\begin{array}{l}30.7 \\
(2.3)\end{array}$ & $\begin{array}{r}30.7 * \\
(3.4)\end{array}$ & $\begin{array}{l}63.9 \\
(3.1)\end{array}$ & $\begin{array}{l}68.6 \\
(4.2)\end{array}$ & $\begin{array}{l}-4.7 \\
(5.3)\end{array}$ & $\begin{array}{l}57.7 \\
(3.9)\end{array}$ & $\begin{array}{l}13.7 \\
(2.1)\end{array}$ & $\begin{array}{r}44.0^{*} \\
(4.0)\end{array}$ & + \\
\hline Four-wheelers & $\begin{array}{r}2.0 \\
(0.7)\end{array}$ & $\begin{array}{r}0.0 \\
(0.0)\end{array}$ & $\begin{array}{l}1.5 * \\
(0.7)\end{array}$ & $\begin{array}{r}2.5 \\
(1.0)\end{array}$ & $\begin{array}{r}0.8 \\
(0.8)\end{array}$ & $\begin{array}{r}1.7 \\
(1.5)\end{array}$ & $\begin{array}{r}0.6 \\
(0.6)\end{array}$ & $\begin{array}{r}0.0 \\
(0.0)\end{array}$ & $\begin{array}{r}0.6 \\
(0.1)\end{array}$ & \\
\hline $\begin{array}{c}\text { Radio/tape- } \\
\text { recorder }\end{array}$ & $\begin{array}{l}10.0 \\
(1.5)\end{array}$ & $\begin{array}{r}4.7 \\
(1.1)\end{array}$ & $\begin{array}{l}5.2 * \\
(1.8)\end{array}$ & $\begin{array}{l}13.9 \\
(2.2)\end{array}$ & $\begin{array}{l}10.5 \\
(2.8)\end{array}$ & $\begin{array}{r}3.4 \\
(3.7)\end{array}$ & $\begin{array}{r}4.3 \\
(1.6)\end{array}$ & $\begin{array}{r}2.2 \\
(0.8)\end{array}$ & $\begin{array}{r}2.1 \\
(1.7)\end{array}$ & \\
\hline $\begin{array}{l}\text { TV-Black/ } \\
\text { white }\end{array}$ & $\begin{array}{r}7.7 \\
(1.3)\end{array}$ & $\begin{array}{r}1.0 \\
(0.5)\end{array}$ & $\begin{array}{l}6.7^{*} \\
(1.4)\end{array}$ & $\begin{array}{r}3.8 \\
(1.2)\end{array}$ & $\begin{array}{r}0.0 \\
(0.0)\end{array}$ & $\begin{array}{l}3.8^{*} \\
(1.7)\end{array}$ & $\begin{array}{l}13.5 \\
(2.7)\end{array}$ & $\begin{array}{r}1.4 \\
(0.7)\end{array}$ & $\begin{array}{r}12.1^{*} \\
(2.3)\end{array}$ & + \\
\hline TV-Color & $\begin{array}{l}38.7 \\
(2.4)\end{array}$ & $\begin{array}{l}23.4 \\
(2.1)\end{array}$ & $\begin{array}{r}15.2 * \\
(3.2)\end{array}$ & $\begin{array}{l}48.3 \\
(3.2)\end{array}$ & $\begin{array}{l}58.1 \\
(4.5)\end{array}$ & $\begin{array}{l}-9.7 * \\
(5.5)\end{array}$ & $\begin{array}{l}24.5 \\
(3.4)\end{array}$ & $\begin{array}{r}7.9 \\
(1.6)\end{array}$ & $\begin{array}{r}16.6^{*} \\
(3.3)\end{array}$ & + \\
\hline $\begin{array}{l}\text { Cable } \\
\text { Connection }\end{array}$ & $\begin{array}{l}24.4 \\
(2.1)\end{array}$ & $\begin{array}{l}13.0 \\
(1.7)\end{array}$ & $\begin{array}{r}11.5^{*} \\
(2.7)\end{array}$ & $\begin{array}{l}31.0 \\
(3.0)\end{array}$ & $\begin{array}{l}33.1 \\
(4.2)\end{array}$ & $\begin{array}{l}-2.0 \\
(5.2)\end{array}$ & $\begin{array}{l}14.7 \\
(2.8)\end{array}$ & $\begin{array}{r}4.0 \\
(1.2)\end{array}$ & $\begin{array}{r}10.8^{*} \\
(2.6)\end{array}$ & + \\
\hline Refrigerator & $\begin{array}{l}15.5 \\
(1.8)\end{array}$ & $\begin{array}{l}14.2 \\
(1.7)\end{array}$ & $\begin{array}{r}1.2 \\
(2.5)\end{array}$ & $\begin{array}{l}18.9 \\
(2.5)\end{array}$ & $\begin{array}{l}39.5 \\
(4.4)\end{array}$ & $\begin{array}{r}-20.6^{*} \\
(4.7)\end{array}$ & $\begin{array}{l}10.4 \\
(2.4)\end{array}$ & $\begin{array}{r}2.9 \\
(1.0)\end{array}$ & $\begin{array}{l}7.5^{*} \\
(2.3)\end{array}$ & + \\
\hline $\begin{array}{l}\text { Gas } \\
\text { Connection }\end{array}$ & $\begin{array}{l}23.9 \\
(2.1)\end{array}$ & $\begin{array}{l}10.5 \\
(1.5)\end{array}$ & $\begin{array}{r}13.5^{*} \\
(2.6)\end{array}$ & $\begin{array}{l}28.2 \\
(2.9)\end{array}$ & $\begin{array}{l}26.6 \\
(4.0)\end{array}$ & $\begin{array}{r}1.5 \\
(5.0)\end{array}$ & $\begin{array}{r}17.8 \\
(0.3)\end{array}$ & $\begin{array}{r}3.3 \\
(1.1)\end{array}$ & $\begin{array}{r}14.5^{*} \\
(2.7)\end{array}$ & + \\
\hline $\begin{array}{l}\text { Sewing } \\
\text { Machine }\end{array}$ & $\begin{array}{r}7.2 \\
(1.3)\end{array}$ & $\begin{array}{r}2.7 \\
(0.8)\end{array}$ & $\begin{array}{l}4.5^{*} \\
(1.5)\end{array}$ & $\begin{array}{r}9.7 \\
(1.9)\end{array}$ & $\begin{array}{r}3.2 \\
(1.6)\end{array}$ & $\begin{array}{l}6.4^{*} \\
(2.9)\end{array}$ & $\begin{array}{r}3.7 \\
(1.5)\end{array}$ & $\begin{array}{r}2.5 \\
(0.9)\end{array}$ & $\begin{array}{r}1.2 \\
(1.7)\end{array}$ & + \\
\hline Mobile Phone & $\begin{array}{l}87.8 \\
(1.6)\end{array}$ & $\begin{array}{l}58.6 \\
(2.5)\end{array}$ & $\begin{array}{r}29.2 * \\
(3.0)\end{array}$ & $\begin{array}{l}92.0 \\
(1.8)\end{array}$ & $\begin{array}{r}79.8 \\
(3.6)\end{array}$ & $\begin{array}{r}12.2 * \\
(3.6)\end{array}$ & $\begin{array}{l}81.6 \\
(3.0)\end{array}$ & $\begin{array}{l}49.1 \\
(3.0)\end{array}$ & $\begin{array}{r}32.5^{*} \\
(4.6)\end{array}$ & + \\
\hline Bank account & $\begin{array}{r}95.5 \\
(1.0) \\
\end{array}$ & $\begin{array}{r}74.3 \\
(2.2) \\
\end{array}$ & $\begin{array}{r}21.2 * \\
(2.4) \\
\end{array}$ & $\begin{array}{l}96.0 \\
(1.3) \\
\end{array}$ & $\begin{array}{l}84.8 \\
(3.3) \\
\end{array}$ & $\begin{array}{r}11.9 * \\
(3.0) \\
\end{array}$ & $\begin{array}{l}95.1 \\
(1.7) \\
\end{array}$ & $\begin{array}{r}70.0 \\
(2.7) \\
\end{array}$ & $\begin{array}{r}25.1 * \\
(3.8) \\
\end{array}$ & + \\
\hline $\mathrm{N}$ & 401 & 401 & & 238 & 124 & & 163 & 277 & & \\
\hline
\end{tabular}

Note: * indicates that the difference in asset ownership between the resettled and semi-submerged households is statistically significant at a $10 \%$ confidence interval. Figures in parentheses are standard errors. In column X, + indicates that the figures for each outcome in columns VI and IX are statistically different at a $10 \%$ confidence interval.

The survey showed unambiguously that the resettled villagers were better off in the ownership of consumer durables (Table 1, columns I, II, and III). For the resettled and semievacuated villages respectively, the ownership of bicycles was $65 \%$ and $31 \%$; of two-wheelers was $61 \%$ and $31 \%$; and of mobile phones was $88 \%$ and $59 \%$. Similar patterns were evident for a 
host of other assets (TVs, four-wheelers, sewing machine, gas and cable connections). As many as $96 \%$ of the resettled families had bank accounts compared $74 \%$ families in semi-submerged villages. There is a similar pattern in asset ownership between ousted families and families in the interior villages (Appendix Table 1).

One source of difference between the treatment and comparison groups could arise on account of their characteristics such as literacy levels and occupation. These differences could be an effect of the resettlement process. For instance, on account of the resettlement program, the resettled families were more likely to own land and therefore engaged in self-cultivation whereas those in semi-evacuated villages were more likely to be marginal farmers or agriculture workers.

To investigate if differences in asset ownership were associated with age and educational attainment of the respondent, we also estimated the gap in asset ownership after controlling for the age (controlling for age and age-squared in the model) and literacy levels of the respondent, and the estimated differences were similar to those reported.

It is often argued that modernization adversely affects forest tribes because it devastates traditional culture and lifestyle, dupes simple tribal folks with little understanding of markets or prices, and destroys their habitat. If this were indeed true, illiterate oustees (who would be more vulnerable to getting duped) would benefit less from resettlement than literate oustees. Our estimates show that the very opposite is true (Table 1, columns IV to X). The improvement in asset ownership between resettled and semi-evacuated villagers was far greater for illiterate households than literate ones. We repeated this analysis using models that controlled for the age of the respondent and results were similar to those reported in Table 1, columns VI and IX. These results confirm that illiterates, the least sophisticated and least conversant with modernization, gained more from resettlement than literates. 
Table 2: Housing Type

\begin{tabular}{|c|c|c|c|c|c|c|c|c|c|c|}
\hline & \multicolumn{3}{|c|}{ All } & \multicolumn{3}{|c|}{ Literate } & \multicolumn{3}{|c|}{ Illiterate } & \\
\hline & Resettled & $\begin{array}{c}\text { Semi- } \\
\text { Submerged }\end{array}$ & Diff & Resettled & $\begin{array}{c}\text { Semi- } \\
\text { Submerged }\end{array}$ & Diff & Resettled & $\begin{array}{c}\text { Semi- } \\
\text { Submerged }\end{array}$ & Diff & \\
\hline & $\mathrm{I}$ & II & $\begin{array}{c}\text { IIII=I- } \\
\text { II }\end{array}$ & IV & $\mathrm{V}$ & $\begin{array}{c}\mathrm{VI}= \\
\mathrm{IV}-\mathrm{V}\end{array}$ & VII & VIII & $\begin{array}{c}\mathrm{XI}=\mathrm{VII} \\
-\mathrm{VIII}\end{array}$ & $\mathrm{X}$ \\
\hline & $\%$ & $\%$ & $\%$ & $\%$ & $\%$ & $\%$ & $\%$ & $\%$ & $\%$ & \\
\hline Mud/thatch & 26.7 & 65.3 & $-38.7^{*}$ & 26.7 & 43.6 & $-16.7 *$ & 26.4 & 75.1 & $-48.7 *$ & + \\
\hline Shanties & $(2.2)$ & (2.4) & (3.2) & (2.9) & $(4.5)$ & (5.1) & (3.5) & (2.6) & (4.3) & \\
\hline $\begin{array}{l}\text { Sem1-brick } \\
\text { shanties }\end{array}$ & 54.9 & 31.2 & $23.7^{*}$ & 49.2 & 47.6 & 1.6 & 63.2 & 23.8 & $39.4 *$ & + \\
\hline & $(2.5)$ & (2.3) & $(3.4)$ & $(3.3)$ & $(4.5)$ & (5.6) & (3.8) & (2.6) & (4.4) & \\
\hline Brick/cement & 18.5 & 3.5 & $15.0^{*}$ & 24.0 & 8.9 & $15.1 *$ & 10.4 & 1.1 & $9.3^{*}$ & \\
\hline & (1.9) & $(0.9)$ & (2.1) & $(2.8)$ & (2.6) & (4.3) & (2.4) & $(0.6)$ & $(2.0)$ & \\
\hline Electricity & 94.5 & 70.8 & $23.7 *$ & 95.8 & 89.5 & $6.3 *$ & 92.6 & 62.5 & $30.2 *$ & + \\
\hline & (1.1) & (2.3) & $(2.5)$ & (1.3) & $(2.8)$ & (2.7) & (2.1) & (2.9) & (4.1) & \\
\hline Running water & 46.4 & 37.4 & $9.0^{*}$ & 42.4 & 59.7 & $-17.2 *$ & 52.2 & 27.4 & $24.7 *$ & + \\
\hline & $(2.5)$ & (2.4) & (3.5) & $(3.2)$ & (4.4) & $(5.5)$ & (3.9) & $(2.7)$ & $(4.6)$ & \\
\hline Drinking water & 45.1 & 33.4 & $11.7 *$ & 41.2 & 50.0 & $-8.8^{*}$ & 50.9 & 26.0 & $24.9^{*}$ & + \\
\hline & $(2.5)$ & (2.4) & $(3.4)$ & $(3.2)$ & $(4.5)$ & $(5.5)$ & $(3.9)$ & (2.6) & (4.6) & \\
\hline $\mathrm{N}$ & 401 & 401 & & 238 & 124 & & 163 & 277 & & \\
\hline
\end{tabular}

Note: * indicates that the difference in asset ownership between the resettled and semi-submerged households is statistically significant at a $10 \%$ confidence interval. Figures in parentheses are standard errors. In column X, + indicates that the figures for each outcome in columns VI and IX are statistically different at a $10 \%$ confidence interval.

The resettled families lived in houses with superior construction (Table 2, columns I to III). They were more likely to live in brick/cement (semi-permanent/permanent) houses with cement walls and concrete roofs than villagers in the two other groups (also see Appendix Table 2 ). The resettled families were more likely to have electricity, drinking and running water than those in semi-submerged villages. Here too we find that the gaps in housing type and access to utilities persist after controlling for age (included as a quadratic function) and literacy. Here too, illiterates have gained much more from resettlement than literates.

Counter-intuitively, literate families in the semi-submerged areas were more likely to have access to running and drinking water than literate resettled families. This could be because a large proportion of families in semi-submerged villages had private tube wells on account of lack of access to canal water, an issue we explore below. Among the illiterates, on the other hand, access to running and drinking water was higher for the resettled. One possible explanation (documented below) is that a larger number of literate households in semi-submerged areas had private tube wells compared to illiterate households. 


\section{Occupation}

"The most serious threat to achievement of resettlement and rehabilitation policies may well lie in entanglement in debt cycles, and the resultant loss of land to money lenders or local landowners.” (Morse and Berger, 1992; Sardar Sarovar: Report of the Independent Review)

Table 3: Occupation of the respondent

\begin{tabular}{|c|c|c|c|c|c|c|c|c|c|c|}
\hline & \multicolumn{3}{|c|}{ All } & \multicolumn{3}{|c|}{ Literate } & \multicolumn{3}{|c|}{ Illiterate } & \\
\hline & Resettled & $\begin{array}{r}\text { Semi- } \\
\text { Submerged }\end{array}$ & Diff & Resettled & $\begin{array}{r}\text { Semi- } \\
\text { Submerged }\end{array}$ & Diff & Resettled & $\begin{array}{r}\text { Semi- } \\
\text { Submerged }\end{array}$ & Diff & \\
\hline & $\mathrm{I}$ & II & $\begin{array}{r}\text { IIII }= \\
\text { I-II }\end{array}$ & IV & $\mathrm{V}$ & $\begin{array}{r}\mathrm{VI}= \\
\mathrm{IV}-\mathrm{V}\end{array}$ & VII & VIII & $\begin{array}{r}\mathrm{XI}=\mathrm{VII} \\
-\mathrm{VIII} \\
\end{array}$ & $\mathrm{X}$ \\
\hline & $\%$ & $\%$ & $\%$ & $\%$ & $\%$ & $\%$ & $\%$ & $\%$ & $\%$ & \\
\hline Landowner - self & 82.5 & 64.6 & $18.0^{*}$ & 82.7 & 56.5 & $26.3 *$ & 82.2 & 68.2 & $14.1^{*}$ & + \\
\hline cultivation & (1.9) & $(2.4)$ & $(3.1)$ & $(2.5)$ & $(4.5)$ & $(4.7)$ & $(3.0)$ & $(2.8)$ & $(4.3)$ & \\
\hline Landowner - tenant & 2.7 & 1.7 & 1.0 & 2.9 & 1.6 & 1.3 & 2.5 & 1.8 & 0.6 & \\
\hline cultivation & $(0.8)$ & $(0.7)$ & $(1.0)$ & (1.1) & (1.1) & $(1.7)$ & (1.2) & $(0.8)$ & (1.4) & \\
\hline Agriculture labor/ & 4.0 & 22.9 & $-19.0 *$ & 5.5 & 22.6 & $-17.1 *$ & 1.8 & 23.1 & $-21.3^{*}$ & \\
\hline marginal farmer & $(1.0)$ & $(2.1)$ & $(2.3)$ & $(1.5)$ & (3.8) & $(3.4)$ & (1.1) & $(2.5)$ & (3.4) & \\
\hline Non-agriculture & 1.2 & 2.0 & -0.7 & 1.3 & 1.7 & -0.4 & 1.2 & 2.2 & -0.9 & \\
\hline labor & $(0.6)$ & $(0.7)$ & $(0.9)$ & $(0.7)$ & (1.1) & (1.3) & $(0.9)$ & (0.9) & (1.3) & \\
\hline Other & 1.2 & 0.2 & 1.0 & 1.3 & 0.8 & 0.5 & 1.2 & 0.0 & $1.2 *$ & \\
\hline & $(0.6)$ & $(0.2)$ & $(0.6)$ & $(0.7)$ & $(0.8)$ & $(1.2)$ & $(0.9)$ & $(0.0)$ & $(0.7)$ & \\
\hline $\mathrm{N}$ & 401 & 401 & & 238 & 124 & & 163 & 277 & & \\
\hline
\end{tabular}

Note: * indicates that the difference in asset ownership between the resettled and semi-submerged households is statistically significant at a $10 \%$ confidence interval. Figures in parentheses are standard errors. In column X, + indicates that the figures for each outcome in columns VI and IX are statistically different at a $10 \%$ confidence interval.

The survey findings in Table 3 render baseless the concerns of many activists as well as the World Bank Independent Review (Morse report) about the ability of oustees to keep the government allocated land. Three decades after they were ousted, the resettled families were primarily landowners $(85.2 \%)$ and engaged in farming. Only $6.4 \%$ reported that they were engaged in jobs outside farming, and these would include those who were below the age of 18 when resettled, and hence got no land. Resettled villagers were mostly landowners engaged in self-cultivation (83\%) or tenant cultivation (3\%) and a small minority (4\%) were agricultural laborers/ marginal farmers, the lowest occupational category in India. Land ownership was substantially less among families in semi-submerged (65\%) and interior villages (58\%) who were much more likely to work as agricultural laborers/marginal farmers (see Appendix Table 3).

In qualitative interviews, some resettled families reported leasing out their land and working as laborers because the land they received was of poor quality or because of water scarcity (Das, 2017). In town hall meetings and one-on-one interviews, we also came across oustees who leased in additional land for cultivation. One oustee family that owns 15 acres of 
land leased in an additional 25 acres of land for cultivation and another family that owns 7.5 acres leased in an additional 10 acres for cultivation.

In the semi-evacuated villages, a surprising finding was that illiterates had a higher proportion of landowners than literates. The reason is unclear, but might reflect more aggressive encroachment (later regularized by the government) on the part of illiterates. Only $1.8 \%$ of the illiterate resettled villagers were dependent on agriculture labor compared to $23.1 \%$ of illiterate respondents in semi-evacuated villages. 


\section{Agricultural Practices \& Animal Husbandry}

Table 4: Agricultural Practices

\begin{tabular}{|c|c|c|c|c|c|c|c|c|c|c|}
\hline & \multicolumn{3}{|c|}{ All } & \multicolumn{3}{|c|}{ Literate } & \multicolumn{4}{|c|}{ Illiterate } \\
\hline & Resettled & $\begin{array}{r}\text { Semi- } \\
\text { Submerged }\end{array}$ & Diff & Resettled & $\begin{array}{r}\text { Semi- } \\
\text { submerged }\end{array}$ & Diff & Resettled & $\begin{array}{r}\text { Semi- } \\
\text { submerged }\end{array}$ & Diff & \\
\hline & I & then & $\mathrm{III}=\mathrm{I}-\mathrm{II}$ & IV & $\mathrm{V}$ & $\begin{array}{r}\mathrm{VI}= \\
\mathrm{IV}-\mathrm{V}\end{array}$ & VII & VIII & $\begin{array}{r}\mathrm{XI}=\mathrm{VII}- \\
\mathrm{VIII}\end{array}$ & $\mathrm{X}$ \\
\hline $\begin{array}{l}\text { Cropping } \\
\text { Pattern }\end{array}$ & $\%$ & $\%$ & $\%$ & $\%$ & $\%$ & $\%$ & $\%$ & $\%$ & $\%$ & \\
\hline Toor & $\begin{array}{l}77.1 \\
(2.1)\end{array}$ & $\begin{array}{l}64.3 \\
(2.4)\end{array}$ & $\begin{array}{c}12.7 * \\
(3.2)\end{array}$ & $\begin{array}{l}78.6 \\
(2.7)\end{array}$ & $\begin{array}{l}46.8 \\
(4.5)\end{array}$ & $\begin{array}{r}31.8^{*} \\
(4.9)\end{array}$ & $\begin{array}{l}74.9 \\
(3.4)\end{array}$ & $\begin{array}{l}72.2 \\
(2.7)\end{array}$ & $\begin{array}{r}2.6 \\
(4.4)\end{array}$ & + \\
\hline Bajra & $\begin{array}{l}10.2 \\
(1.5)\end{array}$ & $\begin{array}{r}9.0 \\
(1.4)\end{array}$ & $\begin{array}{r}1.2 \\
(2.1)\end{array}$ & $\begin{array}{l}10.1 \\
(2.0)\end{array}$ & $\begin{array}{l}23.4 \\
(3.8)\end{array}$ & $\begin{array}{r}-13.3 * \\
(3.9)\end{array}$ & $\begin{array}{l}10.4 \\
(2.4)\end{array}$ & $\begin{array}{r}2.5 \\
(0.9)\end{array}$ & $\begin{array}{l}7.9 * \\
(2.2)\end{array}$ & + \\
\hline Jawar & $\begin{array}{l}15.2 \\
(1.8)\end{array}$ & $\begin{array}{l}34.7 \\
(2.4)\end{array}$ & $\begin{array}{r}-19.5 * \\
(3.0)\end{array}$ & $\begin{array}{l}15.6 \\
(2.4)\end{array}$ & $\begin{array}{l}50.0 \\
(4.5)\end{array}$ & $\begin{array}{r}-34.5 * \\
(4.6)\end{array}$ & $\begin{array}{l}14.7 \\
(2.8)\end{array}$ & $\begin{array}{l}27.8 \\
(2.7)\end{array}$ & $\begin{array}{r}-13.1 * \\
(4.1)\end{array}$ & + \\
\hline Makkai/ Corn & $\begin{array}{l}76.3 \\
(2.1)\end{array}$ & $\begin{array}{l}81.8 \\
(1.9)\end{array}$ & $\begin{array}{l}-5.5^{*} \\
(2.9)\end{array}$ & $\begin{array}{l}71.4 \\
(2.9)\end{array}$ & $\begin{array}{l}75.8 \\
(3.9)\end{array}$ & $\begin{array}{l}-4.4 \\
(4.9)\end{array}$ & $\begin{array}{l}83.4 \\
(2.9)\end{array}$ & $\begin{array}{l}84.5 \\
(2.2)\end{array}$ & $\begin{array}{l}-1.0 \\
(3.6)\end{array}$ & \\
\hline Rice & $\begin{array}{l}20.0 \\
(2.0)\end{array}$ & $\begin{array}{l}10.2 \\
(1.5)\end{array}$ & $\begin{array}{l}9.7 * \\
(2.5)\end{array}$ & $\begin{array}{l}15.1 \\
(2.3)\end{array}$ & $\begin{array}{l}14.5 \\
(3.2)\end{array}$ & $\begin{array}{r}0.6 \\
(4.0)\end{array}$ & $\begin{array}{l}27.0 \\
(3.5)\end{array}$ & $\begin{array}{r}8.3 \\
(1.7)\end{array}$ & $\begin{array}{r}18.7 * \\
(3.4)\end{array}$ & + \\
\hline Wheat & $\begin{array}{r}3.0 \\
(0.9)\end{array}$ & $\begin{array}{r}6.2 \\
(1.2)\end{array}$ & $\begin{array}{l}-3.2^{*} \\
(1.5)\end{array}$ & $\begin{array}{r}2.9 \\
(1.1)\end{array}$ & $\begin{array}{l}13.7 \\
(3.1)\end{array}$ & $\begin{array}{r}-10.8 * \\
(2.7)\end{array}$ & $\begin{array}{r}3.1 \\
(1.4)\end{array}$ & $\begin{array}{r}2.9 \\
(1.0)\end{array}$ & $\begin{array}{r}0.2 \\
(1.7)\end{array}$ & + \\
\hline Cotton & $\begin{array}{r}54.4 \\
(2.5) \\
\end{array}$ & $\begin{array}{l}20.7 \\
(2.0) \\
\end{array}$ & $\begin{array}{r}33.7^{*} \\
(3.2) \\
\end{array}$ & $\begin{array}{l}58.4 \\
(3.2) \\
\end{array}$ & $\begin{array}{l}25.0 \\
(3.9) \\
\end{array}$ & $\begin{array}{r}33.4^{*} \\
(5.3) \\
\end{array}$ & $\begin{array}{r}48.6 \\
(3.9) \\
\end{array}$ & $\begin{array}{l}18.8 \\
(2.4) \\
\end{array}$ & $\begin{array}{r}29.7^{*} \\
(4.3) \\
\end{array}$ & \\
\hline Inputs & & & & & & & & & & \\
\hline $\begin{array}{l}\text { Pesticides/ } \\
\text { Insecticides }\end{array}$ & $\begin{array}{l}93.0 \\
(1.3)\end{array}$ & $\begin{array}{l}67.3 \\
(2.3)\end{array}$ & $\begin{array}{r}25.7 * \\
(2.7)\end{array}$ & $\begin{array}{l}92.4 \\
(1.8)\end{array}$ & $\begin{array}{l}79.8 \\
(3.6)\end{array}$ & $\begin{array}{r}12.6^{*} \\
(3.5)\end{array}$ & $\begin{array}{l}93.9 \\
(1.9)\end{array}$ & $\begin{array}{r}61.7 \\
92.9)\end{array}$ & $\begin{array}{r}32.1 * \\
(4.1)\end{array}$ & + \\
\hline Fertilizers & $\begin{array}{l}86.0 \\
(1.7)\end{array}$ & $\begin{array}{l}52.4 \\
(2.5)\end{array}$ & $\begin{array}{r}33.7^{*} \\
(3.0)\end{array}$ & $\begin{array}{l}84.9 \\
(2.3)\end{array}$ & $\begin{array}{r}71.8 \\
(4.1)\end{array}$ & $\begin{array}{r}13.1^{*} \\
(4.4)\end{array}$ & $\begin{array}{l}87.7 \\
(2.6)\end{array}$ & $\begin{array}{l}43.7 \\
(3.0)\end{array}$ & $\begin{array}{r}44.0^{*} \\
(4.4)\end{array}$ & + \\
\hline Manure & $\begin{array}{r}84.0 \\
(1.8) \\
\end{array}$ & $\begin{array}{r}78.6 \\
(2.1) \\
\end{array}$ & $\begin{array}{l}5.5^{*} \\
(2.8) \\
\end{array}$ & $\begin{array}{l}80.7 \\
(2.6) \\
\end{array}$ & $\begin{array}{r}76.6 \\
(3.8) \\
\end{array}$ & $\begin{array}{r}4.1 \\
(4.5) \\
\end{array}$ & $\begin{array}{l}89.0 \\
(2.5) \\
\end{array}$ & $\begin{array}{r}79.4 \\
(2.4) \\
\end{array}$ & $\begin{array}{l}9.5^{*} \\
(3.7) \\
\end{array}$ & \\
\hline Equipment & & & & & & & & & & \\
\hline Tractor & $\begin{array}{r}6.0 \\
(1.2)\end{array}$ & $\begin{array}{r}0.5 \\
(0.4)\end{array}$ & $\begin{array}{l}5.5^{*} \\
(1.2)\end{array}$ & $\begin{array}{r}4.6 \\
(1.4)\end{array}$ & $\begin{array}{r}0.0 \\
(0.0)\end{array}$ & $\begin{array}{l}4.6^{*} \\
(1.9)\end{array}$ & $\begin{array}{r}8.0 \\
(2.1)\end{array}$ & $\begin{array}{r}0.7 \\
(0.5)\end{array}$ & $\begin{array}{l}7.3^{*} \\
(1.8)\end{array}$ & \\
\hline Thresher & $\begin{array}{r}3.5 \\
(0.9)\end{array}$ & $\begin{array}{r}0.5 \\
(0.4)\end{array}$ & $\begin{array}{l}3.0 * \\
(1.0)\end{array}$ & $\begin{array}{r}2.5 \\
(1.0)\end{array}$ & $\begin{array}{r}0.0 \\
(0.0)\end{array}$ & $\begin{array}{l}2.5^{*} \\
(1.4)\end{array}$ & $\begin{array}{r}4.9 \\
(1.7)\end{array}$ & $\begin{array}{r}0.7 \\
(0.5)\end{array}$ & $\begin{array}{l}4.2^{*} \\
(1.5)\end{array}$ & \\
\hline $\begin{array}{l}\text { Pump/private } \\
\text { Tube well }\end{array}$ & $\begin{array}{r}16.0 \\
(1.8) \\
\end{array}$ & $\begin{array}{r}13.5 \\
(1.7) \\
\end{array}$ & $\begin{array}{r}2.5 \\
(2.5) \\
\end{array}$ & $\begin{array}{l}17.7 \\
(2.5) \\
\end{array}$ & $\begin{array}{l}25.8 \\
(4.0) \\
\end{array}$ & $\begin{array}{l}-8.2 * \\
(4.5) \\
\end{array}$ & $\begin{array}{l}13.5 \\
(2.7) \\
\end{array}$ & $\begin{array}{r}7.9 \\
(1.6) \\
\end{array}$ & $\begin{array}{l}5.6^{*} \\
(3.0) \\
\end{array}$ & + \\
\hline $\mathrm{N}$ & 401 & 401 & & 238 & 124 & & 163 & 277 & & \\
\hline
\end{tabular}

Note: * indicates that the difference in asset ownership between the resettled and semi-submerged households is statistically significant at a 10\% confidence interval. Figures in parentheses are standard errors. In column X, + indicates that the figures for each outcome in columns VI and IX are statistically different at a $10 \%$ confidence interval.

The resettled families differed from the families in semi-submerged villages in terms of their agricultural practices (Table 4). The semi-evacuated groups grew mostly coarse grains and toor dal (a kind of lentil) that do not require expensive purchased inputs (like fertilizers and 
pesticides) or irrigation. The resettled villagers had substantially larger areas under crops requiring expensive purchased inputs and irrigation (paddy and cotton). They were more likely to own tractors and threshers. There is a similar difference in agricultural practices between ousted families and families in the interior villages (Appendix Table 4).

The ownership of private tube wells among the oustees was limited (Table 4). One reason is that the oustees had more access to canal irrigation, and therefore they did not require private tubewells. The resettled villagers were also more likely to use pesticides/insecticides, fertilizers, and manure than the semi-evacuated group.

While resettled villagers were more likely to own milch animals (which are relatively expensive and yield a high return), semi-submerged villagers were more likely to own sheep/goats and poultry (which are relatively cheap and so yield a relatively lower return) (Table 5). The resettled villagers had a lower ownership of bullocks than the semi-submerged villages, indicating greater tractorisation and less reliance on ploughing by bullocks. Many activists have highlighted the adverse impact of lost grazing grounds for the oustees. This does show up in the lower ownership of sheep and goats of resettled villagers. But the ownership of milch cows is higher for oustees, suggesting that access to cattle feed and milk markets is, at least for many families, more important than access to forest grazing.

Table 5: Animal Husbandry

\begin{tabular}{|c|c|c|c|c|c|c|c|c|c|c|}
\hline & \multicolumn{3}{|c|}{ All } & \multicolumn{3}{|c|}{ Literate } & \multicolumn{3}{|c|}{ Illiterate } & \\
\hline & Resettled & $\begin{array}{c}\text { Semi- } \\
\text { Submerged }\end{array}$ & Diff & Resettled & $\begin{array}{c}\text { Semi- } \\
\text { Submerged }\end{array}$ & Diff & Resettled & $\begin{array}{c}\text { Semi- } \\
\text { Submerged }\end{array}$ & Diff & \\
\hline & I & II & III=I-II & IV & $\mathrm{V}$ & $\begin{array}{c}\mathrm{VI}= \\
\mathrm{IV}-\mathrm{V}\end{array}$ & VII & VIII & $\begin{array}{c}\text { XI=VII } \\
-\mathrm{VIII}\end{array}$ & $\mathrm{X}$ \\
\hline \multirow{3}{*}{ Milch animals } & $\%$ & $\%$ & $\%$ & $\%$ & $\%$ & $\%$ & $\%$ & $\%$ & $\%$ & \\
\hline & 74.1 & $65.3 *$ & $8.7^{*}$ & 72.3 & 66.9 & 5.3 & 76.7 & 64.6 & $12.1 *$ & \\
\hline & $(2.2)$ & $(2.4)$ & $(3.2)$ & (2.9) & (4.2) & (5.1) & $(3.3)$ & (2.9) & $(4.5)$ & \\
\hline \multirow[t]{2}{*}{ Bullocks } & 59.1 & 67.6 & $-8.5^{*}$ & 58.8 & 53.2 & 5.6 & 59.5 & 74.0 & $-14.5^{*}$ & + \\
\hline & $(2.5)$ & $(2.3)$ & (3.4) & (3.2) & $(4.5)$ & (5.5) & (3.9) & (2.6) & $(4.5)$ & \\
\hline \multirow[t]{2}{*}{ Sheep/goat } & 20.7 & 39.2 & $-18.5^{*}$ & 16.0 & 14.5 & 1.5 & 27.6 & 50.2 & $-22.6^{*}$ & + \\
\hline & $(2.0)$ & (2.4) & $(3.2)$ & $(2.4)$ & (3.2) & (4.0) & (3.5) & (3.0) & $(4.8)$ & \\
\hline \multirow[t]{2}{*}{ Poultry } & 8.7 & 18.5 & $-9.7^{*}$ & 7.1 & 1.6 & $5.5^{*}$ & 11.0 & 26.0 & $-14.9^{*}$ & + \\
\hline & (1.4) & (1.9) & 92.4) & $(1.7)$ & (1.1) & (2.5) & $(2.5)$ & (2.6) & (3.9) & \\
\hline $\mathrm{N}$ & 401 & 401 & & 238 & 124 & & 163 & 277 & & \\
\hline
\end{tabular}

\section{Access to Government Facilities/Schemes}

Table 6 shows that $99 \%$ of the resettled sample reported that they had access to schools compared to $51 \%$ of the villagers in the semi-submerged villages. Improved access was huge for 
illiterates (up from $31.8 \%$ to $98.2 \%$ ), and moderate for literates (up from $94.4 \%$ to $99.6 \%$ ). The resettled sample also had greater access to public health centers and hospitals compared to the semi-submerged sample, and here again the illiterates gained more than the literates.

Interestingly, of the three groups the interior villages had the highest access to public healthcare centers, hospitals, and community centers/panchayat offices (Appendix Table 6). Upon further investigation, we found that this was because of the proximity of interior villages to the Gujarat Mineral Development Corporation facilities.

Literate households in semi-submerged villages had greater access to public tubewells than in resettled villages, possibly because the resettled villages relied on canal water.

Table 6: Access to Government Facilities

\begin{tabular}{|c|c|c|c|c|c|c|c|c|c|c|}
\hline & \multicolumn{3}{|c|}{ All } & \multicolumn{3}{|c|}{ Literate } & \multicolumn{3}{|c|}{ Illiterate } & \\
\hline & Resettled & $\begin{array}{c}\text { Semi- } \\
\text { Submerged }\end{array}$ & Diff & Resettled & $\begin{array}{c}\text { Semi- } \\
\text { Submerged }\end{array}$ & Diff & Resettled & $\begin{array}{c}\text { Semi- } \\
\text { Submerged }\end{array}$ & Diff & \\
\hline & I & II & $\mathrm{III}=\mathrm{I}-\mathrm{II}$ & IV & $\mathrm{V}$ & $\begin{array}{c}\mathrm{VI}= \\
\mathrm{VI}-\mathrm{V}\end{array}$ & VII & VIII & $\begin{array}{c}\mathrm{XI}=\mathrm{VII} \\
\text {-VIII }\end{array}$ & $\mathrm{X}$ \\
\hline & $\%$ & $\%$ & $\%$ & $\%$ & $\%$ & $\%$ & $\%$ & $\%$ & $\%$ & \\
\hline Public Tubewell & 25.7 & 29.9 & -4.2 & 23.5 & 41.1 & $-17.6^{*}$ & 28.8 & 24.9 & 3.9 & + \\
\hline & $(2.2)$ & (2.3) & $(3.2)$ & $(2.8)$ & (4.4) & $(5.0)$ & (3.6) & $(2.7$ & $(4,4)$ & \\
\hline School & 99.0 & 51.1 & $47.9^{*}$ & 99.6 & 94.4 & $5.2 *$ & 98.2 & 31.8 & $66.4^{*}$ & + \\
\hline & $(0.5)$ & $(2.5)$ & $(2.5)$ & $(0.4)$ & (2.1) & (1.6) & (1.1) & (2.3) & (3.7) & \\
\hline Public Health & 37.4 & 12.5 & $24.9^{*}$ & 34.9 & 9.7 & $25.2 *$ & 41.1 & 13.7 & $27.4 *$ & \\
\hline Centre & $(2.4)$ & (1.7) & (2.9) & (3.1) & $(2.7)$ & (4.7) & (1.4) & (2.4) & $(4.0)$ & \\
\hline Hospital & 14.0 & 3.5 & $10.5^{*}$ & 13.9 & 8.1 & 5.8 & 14.1 & 1.4 & $12.7 *$ & + \\
\hline & $(1.7)$ & $(0.9)$ & $(2.0)$ & $(2.2)$ & $(2.5)$ & (3.6) & (2.7) & (1.4) & (2.3) & \\
\hline Panchayat or & 36.7 & 31.9 & 4.7 & 39.1 & 53.2 & $-14.2 *$ & 33.1 & 22.4 & $10.7^{*}$ & + \\
\hline community office & $(2.4)$ & $(2.3)$ & $(3.4)$ & $(3.2)$ & $(4.5)$ & $(5.5)$ & $(3.7)$ & $(2.5)$ & $(4.3)$ & \\
\hline $\mathrm{N}$ & 401 & 401 & & 238 & 124 & & 163 & 277 & & \\
\hline
\end{tabular}

Note: * indicates that the difference in asset ownership between the resettled and semi-submerged households is statistically significant at a $10 \%$ confidence interval. (Tubewells are generally provided by the government to the community.) Figures in parentheses are standard errors. In column $\mathrm{X},+$ indicates that the figures for each outcome in column VI and IX are statistically different at a 10\% confidence interval.

\section{Impact on tribal culture and traditions}

"There are social and cultural factors that could well determine the long-term outcome of the resettlement and rehabilitation program." (Morse and Berger, 1992; Sardar Sarovar: Report of the Independent Review)

Many earlier studies showed substantial difficulties faced by displaced villagers in the new environments into which resettlement thrust them (Baviskar, 1995, 1997, Hakim, 1997). Our survey suggests that the long-run outcomes have been far more satisfactory, and transitional problems have substantially been overcome. The vast majority of resettled villagers said they 
were able to adjust to new conditions within a few years, had harmonious relations with the higher-caste folk in the new villages where they were relocated, and had not suffered discrimination or hostility (Table 7). A minority disagreed, so there were differing opinions. More tribals than not agreed with the proposition "At times we feel that we have been socially cut-off and uprooted after moving out of the dam affected area." In one-on-one interviews with the researchers, the resettled tribals mentioned that the first two years after resettlement were often difficult because they had to learn new techniques of growing crops like paddy. But within one or two years, they learned the techniques from local neighbors, in particular from local landless laborers, and which they applied to get better yields. Their transition period to modern agriculture was short and relatively smooth, contrary to the dismal predictions of critics (see section on qualitative study).

What was the impact of resettlement on the religious practices, customs and rituals of the ousted families? Our survey results show that, three decades after resettlement, $60 \%$ of the oustee families said that rehabilitation had no effect on their religious practices, $56 \%$ said their traditional customs and rituals have remained unaffected. A majority, 58\%, said that there was no change in their social status, suggesting that they had not been forced down the social ladder by upper castes in the host villages where they were resettled. A significant minority (22\%) disagreed (Table 7).

Earlier researchers reported damaging impacts of resettlement on religious practices, traditional customs and social status (see studies in Dr ze et al., 1997). They focused on transitional impacts, whereas our research shows that long-term outcomes were far more favorable. Consider the following passage from a book review of a 1997 book containing papers on the Narmada resettlement by distinguished academics and activists. "The evidence provided by several papers suggests that the existing experience of rehabilitation has almost entirely been an unhappy one... All these studies show that there are a wide variety of benefits that cannot be replaced in the new sites to which people are shifted-e.g., a sense of community, which concretely manifests itself in mutual labor arrangements; loss of access to common property resources (forests, grazing grounds, rivers); and loss of encroached land which often formed a major portion of land cultivated as against the land to which people had legal title. Other common issues highlighted are changes in the status of women, even as their daily tasks like grinding may become easier; increasing monetization and tenuous relations to "host" villages." (p. 230, Sundar, 1999).

The problem with this analysis is that it focuses entirely on losses from change while saying absolutely nothing on the gains. Indeed, this book review ignores even those chapters in the book that show resettlement in a more favorable light. Likewise, many other critics seem to attach little or no importance to the fact that forest tribals have far less access to schools, healthcare, roads, electricity, jobs, and the many comforts of modern life. Vidyut Joshi, one of the authors in the book, emphasizes that to say tribals are different and must not be disturbed is to deny them the right to development. 
Table 7: Social Impact: Views of the Resettled

\begin{tabular}{ccc} 
Agree & \multicolumn{1}{c}{$\begin{array}{c}\text { Neither } \\
\text { Agree nor } \\
\text { Disagree }\end{array}$} & Disagree \\
\cline { 2 - 3 }$\%$ & $\%$ & $\%$ \\
\hline
\end{tabular}

There is no change in our religious practices after rehabilitation

60

There was no change in the traditional customs and rituals after rehabilitation

There is no change in our rituals and practices after rehabilitation

We have adjusted well in this new village and face no discrimination from the villagers

Our attire has changed after resettlement and we prefer it

Inter-caste marriages have gone up

There has been an increase in dowry in marriages

We are now allowed to pursue an economic activity apart from doing household chores

At times we feel that we have been socially cut-off and uprooted after moving out of the dam affected area There is no change in our Social Status

Our household income and oportunities of employment have improved substantially after moving out of the dam affected area

\section{Neither}

Agree nor

Disagree

$\%$

20

19

56

21

21

58

20

22

57

52

51

44

61

44

58

48
39

19

17

22

19

25

20

20

25

14

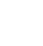

27

Views on the social impact of resettlement were statistically the same among young and old respondents, but varied significantly by literacy levels of the respondent (Appendix Table 7). The literate respondents were more likely to agree (and less likely to disagree) that their religious practices, traditional customs and rituals were unaffected after resettlement. They were also less likely to agree that inter-caste marriages and dowry increased after resettlement. 


\section{Given a choice, would they like to go back?}

The resettled villagers were asked whether, given the choice, they would prefer to go back to their old villages with the same land they had earlier (Table 8). A majority (54\%) said they would like to go back. This shows that material possessions are not the only criteria for location preference: nostalgia and attachment to the land of ancestors and sacred forest sites can be more important. Activists may argue that the main reason for wanting to return is access to forest resources (grazing, fruit, herbs, firewood), but our data show that in material terms those in the forest are worse off, so those who want to go back probably have non-material priorities. The semi-evacuated and interior villagers were asked whether, given the option of getting the resettlement compensation package, they would like to move. In the semi-evacuated areas, $31 \%$ wanted to move, $53 \%$ wanted to stay, and the rest gave no opinion. Those wanting to move were more likely to be young (under 40 ). In the interior areas, a majority (52\%) wanted to move, $35 \%$ wanted to stay and $13 \%$ voiced no opinion. In the interior villages, those wanting to move were more likely to be older (over 40). Clearly significant proportions of tribal groups, and in some cases a majority, want to leave the forests and join the mainstream. 


\begin{tabular}{|c|c|c|c|c|c|c|c|c|c|}
\hline & \multicolumn{3}{|c|}{ All } & \multicolumn{3}{|c|}{$<40$ years } & \multicolumn{3}{|c|}{$>40$ years } \\
\hline & Agree & Neither & Disagree & Agree & Neither & Disagree & Agree & Neither & Disagree \\
\hline & Yes & No & & & & & & & \\
\hline $\begin{array}{l}\text { Resettled villagers } \\
\text { If the government offers the exact } \\
\text { amount of land you had earlier in the } \\
\text { higher un-submerged part of your old } \\
\text { village in exchange for the land you } \\
\text { have today, you will accept it. }\end{array}$ & 54 & 15 & 30 & 53 & 18 & 28 & 56 & 14 & 32 \\
\hline $\begin{array}{l}\text { Semi-submerged } \\
\text { I would be willing to give up my } \\
\text { land, livestock and accept the } \\
\text { government's rehabilitation package } \\
\text { today }\end{array}$ & 31 & 16 & 53 & 36 & 15 & 50 & 26 & 18 & 56 \\
\hline $\begin{array}{l}\text { We think that we would have been } \\
\text { economically better off if we had } \\
\text { been rehabilitated }\end{array}$ & 31 & 17 & 52 & 37 & 15 & 48 & 26 & 18 & 55 \\
\hline $\begin{array}{l}\text { Interior Villagers } \\
\text { I would be willing to give up my } \\
\text { land, livestock and accept the } \\
\text { government's rehabilitation package } \\
\text { today }\end{array}$ & 52 & 13 & 35 & 42 & 15 & 43 & 59 & 11 & 30 \\
\hline $\begin{array}{l}\text { We think that we would have been } \\
\text { economically better off if we had } \\
\text { been rehabilitated }\end{array}$ & 54 & 11 & 36 & 47 & 12 & 41 & 58 & 10 & 31 \\
\hline
\end{tabular}




\section{Qualitative Study}

In town hall meetings and detailed interviews, resettled families painted a rosier picture of the impact of resettlement than revealed in the quantitative survey. The resettled villages were better connected than the original villages and had better facilities including schools, hospitals, banks, electricity and water.

While response varied across villages, the qualitative report describes the opportunities and constraints as follows: "There appear to be far better facilities in the treatment group villages than in the earlier villages. Often support network was present as people belonged to the same community. Education and livelihood opportunities were better. Girls could also study and learn to use computers. Both boys and girls went to college and literacy rate went up in most villages. There were better livelihood opportunities as well. Good milk output was another common output which was sold to the local dairy. Farming income doubled in most resettled areas because of fertile land and availability of irrigation facilities." (Das, 2017).

"While most people had a better standard of living, a few missed the access they had to the nearby forest in their original place of settlement. Be it agricultural land, wood, fodder, natural resources for them and also grazing fields for their cattle." (Das, 2017).

Possibly the qualitative study was able to capture certain aspects of living that survey interviews missed. We believe the difference may also reflect the fact that respondents were more out-spoken and candid in one-on-one interviews and surveys conducted in privacy than in town hall meetings in the presence of other members of their community as well as NGO representatives.

\section{Complaints}

In one-on-one interviews, many resettled villagers had a variety of complaints. Government officials said the complaints cover approximately 7 percent of the oustees. The biggest grievance was that of men who were below the age of 18 in the cut-off year of resettlement, and so got no land whereas their older brothers and fathers got five acres each. Those who complain about not receiving land on account of the 18+ cut-off, believe that if they had remained in the jungle, they would have been able to capture enough land to meet their need for cultivation. Many said they had not gotten jobs as promised. Some complained that they did not get grazing land for their animals and some complained about water and land quality problems.

Most resettled tribals mentioned that they appreciate the ease of tribal life, and still remember the stress of leaving their ancestral lands. Nostalgia about the life left behind, including access to forest resources, continues to linger. 
Our study is limited to resettlement of Gujarat oustees. It does not cover resettlement of oustees from Maharashtra of Madhya Pradesh (numbering approximately 4,000 and 38,000 families respectively), who were mostly resettled in their own states (though a limited number opted to be resettled in Gujarat). According to most reports, Gujarat has been more successful in resettlement than the other two states. Agitations of dissatisfied tribals from all three states are still continuing three decades after displacement.

We restricted our study to project affected families in Gujarat for several reasons. First, we had budget constraints. Second, it made sense to focus on the claims of the state that was reputed to have done best. Third, comparable groups (to test the counterfactual) were easily available in Gujarat.

\section{Conclusion}

Our study has three major conclusions. First, Gujarat has demonstrated that it is entirely possible to implement rehabilitation packages that leave the oustees substantially better off in material terms. The dire predictions of anti-dam activists were hugely exaggerated. Despite many grievances of the oustees and shortcomings in implementation, the Gujarat government has, overall, ensured higher living standards for oustees. This sets an example for other states, whose performance has sometimes been terrible.

Second, the study disproves the claim of activists (and the Morse Commission report) that tribals have such a different ethos and lifestyle that they will be devastated and impoverished if shifted to mainstream villages. Ownership of cellphones, bank accounts, and Aadhar cards is close to universal in the resettled villages. Our survey documents that tribals have adjusted and prospered. Far from losing their land to the Patels (land owning caste), as predicted by the Morse Committee and several activists, a number of oustees have leased land from the Patels to expand their cultivated area. The argument that the tribals will not be able to transition from subsistence agriculture to commercial cropping has also been disproved by our survey. More than half the respondents in our resettled sample grew cash crops and a vast majority (close to $90 \%$ ) used pesticides or chemical fertilizers.

Third, any blanket statement about the ethos and attitudes of tribals is unwarranted---they exhibit a wide spectrum of views on changes after resettlement, and whether they would prefer the forest or the mainstream. While the thesis that tribals should be protected from modernization looks weak, the willingness of over half the resettled villagers to return to their old forest habitat, despite being materially better off, shows that forced resettlement places considerable stress on oustees, so great care is needed to design rehabilitation packages that alleviate the economic and social stress. 


\section{References}

Alvares, Claude and Ramesh Billorey. 1987. Damming The Narmada India Greatest Planned Environmental Disaster, ePub eBook

Baviskar, Amita. 1995. In the Belly of the River: Tribal Conflicts over Development in the Narmada Valley. Delhi: Oxford University Press.

Baviskar, Amita. 1997. "Displacement and the Bhilala Tribals of the Narmada Valley" in The Dam and the Nation: Displacement and Resettlement in the Narmada Valley". Eds. Dr ze, Jean, Meera Samson, and Satyajit Singh.

Bhatia, Bela. 1997. "Forced Evictions in the Narmada Valley" in The Dam and the Nation: Displacement and Resettlement in the Narmada Valley". Eds. Dr ze, Jean, Meera Samson, and Satyajit Singh.

Das Udita. 2017. "Qualitative report on impact assessment of resettlement and rehabilitation initiatives of Sardar Sarovar project on families affected in Gujarat.” Karvy Insights Report.

Hakim, Roxanne. 1997. "Resettlement and Rehabilitation in the Context of "Vasava' culture" in The Dam and the Nation: Displacement and Resettlement in the Narmada Valley”. Eds. Dr ze, Jean, Meera Samson, and Satyajit Singh.

Joshi, Vidyut. "Rehabilitation in the Narmada Valley: Human Rights and National Policy Issues" in The Dam and the Nation: Displacement and Resettlement in the Narmada Valley". Eds. Dr ze, Jean, Meera Samson, and Satyajit Singh.

Morse, Bradford and Thomas Berger. 1992. "Sardar Sarovar: Report of the Independent Review", Ottawa: Resource Futures International inc.

Patkar, Medha. 2017. "Discourse on Development, Displacement and Human Rights Cocerns. A discourse", Public Lecture on the occasion of the Golden Jubilee Celebrations of the Department of Social Work, Jamia Millia Islamia.

https://video.search.yahoo.com/yhs/search?fr=yhs-adk-adk_sbnt\&hsimp=yhsadk sbnt\&hspart $=$ adk \&p=medha + patkar + on + tribals + and + narmada $\#$ id $=3 \& v i d=0 e 6 a 1 d 6354 f 8 f c a$ $\underline{\mathrm{d} 90 \mathrm{fb} 089 \mathrm{~cd} 603 \mathrm{~b} 252 \text { \&action=view }}$ (downloaded September 17, 2017).

Medha Patkar. 1995. (in conversation with Smithu Kothari. The Struggle for Participation and Justice: a Historical Narrative. Chapter in William F Fisher (eds) Towards Sustainable Development: Struggling over India's Narmada River. M.E.Sharpe Publishers. pp 157-178. 
Sunder, Nandini. Book Review: The Dam and the Nation: Displacement and Resettlement in the Narmada Valley. The Journal of Asian Studies, Vol. 58, No. 1 (Feb., 1999), pp. 229-230 
Appendix Table 1: Asset Ownership

\begin{tabular}{lrr}
\hline & Resettled & Interior Villages \\
\hline \multirow{3}{*}{ Bicycles } & $\mathbf{\%}$ & $\mathbf{\%}$ \\
& 65.0 & $48.0^{*}$ \\
Two-wheelers & $(2.4)$ & $(2.5)$ \\
& 61.0 & $46.0^{*}$ \\
Four-wheelers & $(2.4)$ & $(2.5)$ \\
& 2.0 & $0.0^{*}$ \\
Radio/tape-recorder & $(0.7)$ & $(0.0)$ \\
& 10.0 & $7.7^{\circ}$ \\
TV-Black/white & $(1.5)$ & $(1.3)$ \\
& 7.7 & $4.7^{*}$ \\
TV-Color & $(1.3)$ & $(1.1)$ \\
& 38.7 & 35.8 \\
Cable Connection & $(2.4)$ & $(2.4)$ \\
& 24.4 & $19.4^{*}$ \\
Refrigerator & $(2.1)$ & $(2.0)$ \\
& 15.5 & $20.9^{*}$ \\
Gas Connection & $(1.8)$ & $(2.0)$ \\
Sewing Machine & 23.9 & $18.7^{*}$ \\
& $(2.1)$ & $(1.9)$ \\
Mobile Phone & 7.2 & 5.5 \\
Bank account & $(1.3)$ & $(1.1)$ \\
& 87.8 & $74.6^{*}$ \\
N & $(1.6)$ & $(2.2)$ \\
\hline & 95.5 & 96.3 \\
& $(1.0)$ & $(0.9)$ \\
\hline & 401 & 402 \\
\hline
\end{tabular}

Note: * indicates that the difference in asset ownership between the resettled and interior households is statistically significant at a $10 \%$ confidence interval. Figures in parentheses are standard errors. 
Appendix Table 2: Housing Type

\begin{tabular}{lcc}
\hline & Resettled & Interior \\
\hline Housing & $\mathbf{\%}$ & $\mathbf{\%}$ \\
Mud/thatch Shanties & 26.7 & $37.1^{*}$ \\
& $(2.2)$ & $(2.4)$ \\
Semi-shanties & 54.9 & 50.1 \\
& $(2.5)$ & $(2.5)$ \\
Brick/cement (pukka) & 18.5 & $12.7^{*}$ \\
& $(1.9)$ & $(1.7)$ \\
Have electricity & 94.5 & 93.0 \\
& $(1.1)$ & $(1.3)$ \\
Running water & 46.4 & $65.2^{*}$ \\
& $(2.5)$ & $(2.4)$ \\
Drinking water & 45.1 & $67.4^{*}$ \\
& $(2.5)$ & $(2.3)$ \\
\hline N & 401 & 402 \\
\hline Note: $*$ indicates that the difference in housing type (and other outcomes) between the resettled and interior \\
households is statistically significant at a 10\% confidence interval. Figures in parentheses are standard errors.
\end{tabular}

Appendix Table 3: Occupation of the respondent

\begin{tabular}{lcc}
\hline & Resettled & Interior \\
\hline & $\%$ & $\%$ \\
Landowner - self cultivation & 82.5 & $58.0^{*}$ \\
& $(1.9)$ & $(2.5)$ \\
Landowner - tenant cultivation & 2.7 & 1.2 \\
& $(0.8)$ & $(0.6)$ \\
Agriculture Labor/marginal farmer & 4.0 & $21.6^{*}$ \\
& $(1.0)$ & $(2.1)$ \\
Labor -non-agriculture & 1.2 & $6.7^{*}$ \\
& $(0.6)$ & $(1.2)$ \\
Other & 1.2 & 1.0 \\
& $(0.6)$ & $(0.5)$ \\
\hline $\mathrm{N}$ & 401 & 402 \\
\hline
\end{tabular}

Note: * indicates that the difference in occupation between the resettled and interior households is statistically significant at a $10 \%$ confidence interval. Figures in parentheses are standard errors. 
Appendix Table 4: Agricultural Practices

\begin{tabular}{|c|c|c|}
\hline & Resettled & Interior \\
\hline & $\%$ & $\%$ \\
\hline \multicolumn{3}{|l|}{ Cropping Pattern } \\
\hline \multirow[t]{2}{*}{ Toor } & 77.1 & $60.0^{*}$ \\
\hline & $(2.1)$ & $(2.4)$ \\
\hline \multirow[t]{2}{*}{ Bajra } & 10.2 & $14.7^{*}$ \\
\hline & $(1.5)$ & $(1.8)$ \\
\hline \multirow[t]{2}{*}{ Jawar } & 15.2 & $40.0 *$ \\
\hline & $(1.8)$ & $(2.4)$ \\
\hline \multirow[t]{2}{*}{ Makkai/Corn } & 76.3 & $66.9 *$ \\
\hline & $(2.1)$ & $(2.3)$ \\
\hline \multirow[t]{2}{*}{ Rice } & 20.0 & $14.4^{*}$ \\
\hline & $(2.0)$ & $(1.8)$ \\
\hline \multirow[t]{2}{*}{ Wheat } & 3.0 & 3.0 \\
\hline & $(0.9)$ & $(0.8)$ \\
\hline \multirow[t]{2}{*}{ Cotton } & 54.4 & $44.8^{*}$ \\
\hline & $(2.5)$ & $(2.5)$ \\
\hline \multicolumn{3}{|l|}{ Purchase of Inputs } \\
\hline \multirow[t]{2}{*}{ Pesticides/ Insecticides } & 93.0 & $85.3^{*}$ \\
\hline & $(1.3)$ & $(1.8)$ \\
\hline \multirow[t]{2}{*}{ Fertilizers } & 86.0 & $78.1 *$ \\
\hline & $(1.7)$ & $(2.1)$ \\
\hline \multirow[t]{2}{*}{ Manure } & 84.0 & $78.9 *$ \\
\hline & $(1.8)$ & $(2.0)$ \\
\hline \multicolumn{3}{|l|}{ Equipment } \\
\hline \multirow[t]{2}{*}{ Tractor } & 6.0 & $2.5^{*}$ \\
\hline & $(1.2)$ & $(0.8)$ \\
\hline \multirow[t]{2}{*}{ Thresher } & 3.5 & $0.5^{*}$ \\
\hline & $(0.9)$ & $(0.4)$ \\
\hline \multirow[t]{2}{*}{ Pump/private tube well } & 16.0 & $11.4^{*}$ \\
\hline & $(1.8)$ & $(1.6)$ \\
\hline $\mathrm{N}$ & 401 & 402 \\
\hline
\end{tabular}

Note: ${ }^{*}$ indicates that the difference in agricultural practices between the resettled and interior households is statistically significant at a $10 \%$ confidence interval. Figures in parentheses are standard errors. 
Appendix Table 5: Animal Husbandry

\begin{tabular}{lcc}
\hline & Resettled & Interior \\
\hline Milch animals & $\%$ & $\%$ \\
\multirow{3}{*}{ Bullocks } & 74.1 & $58.7^{*}$ \\
& $(2.2)$ & $(2.5)$ \\
Sheep/goat & 59.1 & 56.2 \\
& $(2.5)$ & $(2.5)$ \\
Poultry & 20.7 & 25.9 \\
& $(2.0)$ & $(2.2)$ \\
$\mathrm{N}$ & 8.7 & $12.9^{*}$ \\
\hline $\mathrm{N}$ & $(1.4)$ & $(1.7)$ \\
\hline
\end{tabular}

Note: * indicates that the difference in ownership of animals between the resettled and interior households is statistically significant at a $10 \%$ confidence interval. Figures in parentheses are standard errors.

\section{Appendix Table 6: Access to Government Facilities}

\begin{tabular}{lcc}
\hline Facilities & Resettled & Interior \\
\hline \multirow{3}{*}{ Public Tubewell } & $\%$ & $\%$ \\
& 25.7 & $46.0^{*}$ \\
School & $(2.2)$ & $(2.5)$ \\
& 99.0 & $76.9^{*}$ \\
Public Health Center & $(0.5)$ & $(2.1)$ \\
& 37.4 & 40.8 \\
Hospital & $(2.4)$ & $(2.5)$ \\
& 14.0 & $30.1^{*}$ \\
Panchayat Office/ Community Center & $(1.7)$ & $(2.3)$ \\
& 36.7 & $58.0^{*}$ \\
$\mathrm{~N}$ & $(2.4)$ & $(2.5)$ \\
\hline
\end{tabular}

Note: * indicates that the difference in access to government facilities between the resettled and interior households is statistically significant at a $10 \%$ confidence interval. Figures in parentheses are standard errors. Tubewells are generally provided by the government to the community. 


\begin{tabular}{|c|c|c|c|c|c|c|c|c|}
\hline & \multicolumn{4}{|c|}{ Agree } & \multicolumn{4}{|c|}{ Disagree } \\
\hline & Young & Old & Illiterate & Literate & Young & Old & Iliterate & Literate \\
\hline & $\%$ & $\%$ & $\%$ & $\%$ & $\%$ & $\%$ & $\%$ & $\%$ \\
\hline $\begin{array}{l}\text { There is no change in our religious practices after } \\
\text { rehabilitation }\end{array}$ & 66 & 57 & 48 & $70 *$ & 14 & 24 & 28 & $14^{*}$ \\
\hline $\begin{array}{l}\text { There was no change in the traditional customs and } \\
\text { rituals after rehabilitation }\end{array}$ & 57 & 56 & 47 & $63^{*}$ & 20 & 23 & 29 & $17^{*}$ \\
\hline $\begin{array}{l}\text { There is no change in our rituals and practices after } \\
\text { rehabilitation }\end{array}$ & 59 & 57 & 46 & $66^{*}$ & 20 & 24 & 31 & $17 *$ \\
\hline $\begin{array}{l}\text { We have adjusted well in this new village and face no } \\
\text { discrimination from the villagers }\end{array}$ & 63 & 53 & 48 & $63 *$ & 19 & $29 *$ & 33 & $19 *$ \\
\hline $\begin{array}{l}\text { Our attire has changed after resettlement and we prefer } \\
\text { it }\end{array}$ & 54 & 50 & 56 & 49 & 25 & 21 & 14 & $28 *$ \\
\hline Inter-caste marriages have gone up & 47 & $54^{*}$ & 64 & $42 *$ & 34 & 25 & 18 & $35^{*}$ \\
\hline There has been an increase in dowry in marriages & 43 & 45 & 62 & $32 *$ & 38 & 34 & 19 & $47 *$ \\
\hline $\begin{array}{l}\text { We are now allowed to pursue an economic activity } \\
\text { apart from doing household chores }\end{array}$ & 58 & 63 & 56 & 64 & 16 & 12 & 11 & 16 \\
\hline $\begin{array}{l}\text { At times we feel that we have been socially cut-off and } \\
\text { uprooted after moving out of the dam affected area }\end{array}$ & 41 & 46 & 43 & 45 & 20 & 15 & 18 & 16 \\
\hline There is no change in our Social Status & 56 & 59 & 54 & $61 *$ & 22 & 22 & 28 & $18^{*}$ \\
\hline $\begin{array}{l}\text { Our household income and oportunities of employment } \\
\text { have improved substantially after moving out of the } \\
\text { dam affected area }\end{array}$ & 42 & 51 & 48 & 47 & 32 & $24^{*}$ & 21 & 32 \\
\hline
\end{tabular}

\footnotetext{
* indicates that the difference in views between young and old (or illiterate and literate) respondents is statistically significant at a $10 \%$ confidence interval.
} 